\title{
Problems and Countermeasures of Education Internship in Local Normal University Biology Major-take Anshun College for Example
}

\author{
Guang $\mathrm{Li}^{1, \mathrm{a}}$, Shuang $\mathrm{Yu}^{1, b^{*}}$ and Yue Qiu ${ }^{1, \mathrm{c}}$ \\ alg20029@126.com, bysling77@ sina.com \\ *the corresponding author
}

College of Resource and Environment, Anshun University, Anshun 561000

Keywords: Provincial normal college; Educational practice; Countermeasure

Abstract. Educational practice is an important part of teaching and education in normal colleges, a significant guarantee to cultivate certify teacher for the society. This paper takes the biology educational practice in Anshun University as an example, analyses the problems appeared in biology educational practice of provincial normal college, and then proposes some countermeasures.

\section{地方师范院校生物专业教育实习存在的问题及对

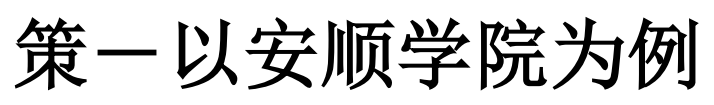

李光，余霜*，邱玥

安顺学院资源与环境工程学院, 安顺 561000

摘要: 教育实习是师范院校教育教学工作的重要组成部分, 是为社会培养合格师资的重要保障。本文以安顺学院生物教 育实习为例, 分析了地方高校生物教育实习中出现的问题, 并对地方高校生物教育实习提出一些积极对策和建议。

关键词: 地方师范院校; 教育实习;对策

\section{1 前言}

教育实习是各级师范院校的教育环节之一, 指学生在教师的指导下, 运用已获得的知识, 在中等学校、 初等学校和幼儿园参加教学和思想政治教育工作。一般在毕业阶段进行, 能加强理论与实际的联系, 培养 学生独立工作能力, 它是各级师范院校教学计划的有机组成部分 [1]。近年来, 随着生物科学的不断发展, 人们更加重视生物学科的学习, 也对生物学教师提出了更高的要求, 而生物教育实习是培养合格生物教师 的重要手段, 各级院校都非常重视这项工作。然而, 当前的生物教育实习还存在许多问题亟待解决。

\section{2 生物教育实习过程中存在的主要问题}

随着各地不断巩固和提高基础教育，学校布局和结构调整力度不断加大，教育资源配置进一步优化， 办学规模不断扩大, 办学效益明显提高的大环境下, 生物教育实习工作取得了一些可喜的成绩, 但由于各 种因素的制约，还是存在一些不足和问题，主要有以下几个方面:

\section{1 教育实习基地缺乏}

正常的情况下, 每位指导教师只能带 1 至 2 名实习生, 在教育实习基地缺乏的情况下, 每位指导教师 可能带 2 名甚至更多的实习生, 导致学生实习质量下降, 这也是是很多院校教育实习中遇到的一个棘手的 问题。目前, 安顺学院的教育实习基地现有 47 个, 其中学校 28 所, 这些学校大多提供生物教育实习的岗 
位, 可以满足该院生物学教育实习的需要, 但是随着学院办学规模的扩大, 还需要进一步扩大实习基地规 模。

\section{2 部分实习生对实习准备不充分}

学生实习前准备不足, 是当前生物教育实习普遍存在的问题。这些不足主要表现在实习生专业素质和 思想上两个方面。第一, 专业素质方面: 实习生的教育教学理论基础不够扎实。这主要表现在他们对中学 教学方法的一般规律、教材特点以及中学生的心理特点和学习特点都不甚了解。造成这种结果的主要原因 是, 一些学生不能够很好的认识到教育学、心理学等课程的重要性, 认为这些课程与专业实际相脱离, 不 愿意认真学习这些课程。另外, 生物教育学、心理学等基础教育教学理论课程的课时比例偏小, 学生不能 够很好的掌握所学的课堂教学方法, 造成了学生知识结构的不合理, 教学基础理论和实践操作能力差的后 果。第二, 思想方面: 在学院动员和鼓舞的推动下, 尽管大部分实习生对教育实习在思想上十分重视, 也 在积极进行准备, 但是心理准备效果不够理想, 主要表现在吃苦意识不够和站在讲台上变现的不知所措等。

\section{3 缺乏有经验的生物专业实习指导教师}

许多实习学校为了不影响自己的教学质量, 不愿意拿自己最好的班级和最有经验的教师作为实习指导 教师, 而是让实习学生到一些普通班去实习, 这样容易打消实习生将来加入教师行列的积极性, 不利于教 育的长期健康发展。安顺学院遇到的这方面的情况更为典型, 安顺学院从 2009 年开始招生生物科学专业 本科生, 在此之前安顺学院只有化学教育 (生物学方向) 专业的部分毕业生从事生物学教学工作, 导致安 顺市及所管县区学校的生物专业教师严重缺少。在 “安顺市西秀区基本普及九年义务教育、基本扫除青壮 年文盲” 检查中, 检查组就曾经发现有中文专业、物理专业、地理专业毕业的教师担任生物学任课教师。 而且呈现出从市区到县城再到乡下, 生物学专业教师缺乏程度逐渐增加的趋势, 以国家级贫困县紫云县白 石岩中学为例, 该校现有教师 29 名, 其中竟无一名生物学专业毕业的教师, 该校的生物学任课教师由化 学专业毕业的教师担任, 这种情况在其他学校也同时存在。这不但是对人才资源的巨大浪费, 也极大的影 响学校的教学质量。

\section{4 教育实习时间过短, 不利于实习生完成从实习生向教师角色的转化}

安顺学院的教育实习时间为 9 周, 除去国庆 1 周, 实际的教学实习时间仅 8 周, 是教育部规定的教育 实习时限的下限, 与西方发达国家差距明显。例如：美国的教育实践分为 “模拟实习、早期实地经验和教 学实习”三种, 累计实践时间达一年 [2]。实习时间明显偏短, 不利于实习生熟悉教学工作的基本环节和 有效地把握教学原则, 也不利于实习生了解中小学教育教学的规律, 更不利于实习生主动地、独立地、创 造性地开展课堂教学、班主任工作、课外活动及教育调查活动。实习时间短也导致实习生刚刚进人教师角 色, 实习就结束了, 很难达到提高实习生教学能力、管理能力, 完成实习生向教师角色转化的目的。同时, 由于实习时间过短, 实习中即使发现了不足, 也没有充分的时间再学习、再实践, 将来他们不得不带着问 题走上工作岗位, 这对实习生自身的成长及中小学的教育都是不利的。

\section{3 建议及对策}

教育实习是一项系统的工程, 需要解决的问题可能有几点, 也可能更多。但由于主观条件和客观条件 的限制, 不能把所有的问题彻底解决, 这里提出一些对策来解决当前所碰到的问题, 并为以后的教育实习 生、指导教师和相关职能部门提供一些参考性的意见, 以便更好地开展实习工作, 提高实习质量。 


\section{1 完善规章制度建设, 保证实习工作的有序进行}

俗话说 “无规矩不成方圆”，为保证学院实习工作的顺利进行，必须把强化制度建设，夯实管理基础 作为一项重点工作。为此, 需建立规章制度修订完善的长效机制, 不断增强制度的科学性、及时性与可操 作性, 确保各项工作规范有序的开展。在今年针对实习生的甲型流感预防工作中, 该院及早出台文件《安 顺学院教育实习预防与控制甲型 H1N1 流感工作预案》，稳定了实习生的军心，确保了教育实习的顺利进 行。

\section{2 认真细致的做好实习前动员工作}

学院应该在实习前积极深入的开展实习前动员和实习带队教师座谈会等工作, 传达有关教育实习的各 项政策, 统一师生的思想认识。并要求实习学生高度认识和深刻理解实习的目的和重要意义, 尽快完成从 学校到社会、从学校到工作岗位、从学生到教师的角色转换, 在实习实践活动中尽快成长, 了解社会, 提 高从教技能和业务水平，实现专业技能和思想觉悟方面的 “双丰收”。同时，要求实习带队教师提高思想 认识, 做好实习学生的表率, 扎下心来工作, 并不断探索和总结实习工作, 推动该院实习工作再上新台阶。

\section{3 积极稳妥的开展顶岗实习工作}

顶岗也就是在实习生修完专业骨干课程和教育课程，经过有针对性的系统培训后，到实习学校进行全 职教师岗位锻炼。同时, 被顶替下来的教师, 利用师范院校的教育教学资源, 开展专业研修和培训。这样, 教师教育和培养的空间由以大学为本的空间模式向以大学为本和中小学为本相结合的空间模式转变 [3]。 不但给实习生提供了更加丰富的实习机会, 而且可以调动实习学校接受实习生的积极性, 实习学校教师素 质和业务水平也会在培训中得到提高, 达到双赢的目的。

\section{4 建立经费保障机制, 拓宽经费筹措渠道}

经费是高质量完成实习任务的重要保证, 教育实习经费不足, 是制约实习工作顺利展开的一个重要因 素。为此, 安顺学院建立了实习专项经费, 并做到专款专用, 为实习工作的顺利开展打好基础。同时, 学 院还积极拓宽经费筹措渠道, 例如：对顶岗置换下来的教师收取适当的培训费，所得费用部分环节补占实 习，极大的缓解了实习经费不足的问题。

总之、生物教育实习是一项系统的工程, 它既是学生的生物学知识与技能、素质与素养的全面整合过 程, 同时也是师范类生物教育不同于其它生物教育的重要特征之一。它不仅关系到广大毕业生的就业和出 路、前途和命运, 而且与学院的生源和质量、生存和发展息息相关。因而, 对于生物教育实习工作, 每位 教职工责无旁贷，不可袖手旁观。

\section{作者简介：}

李光 (1980-), 男, 河南商丘人, 博士，教授。主要从事农业资源、作物遗传育种研究。E-mai1: 1g20029@126.com。

*通讯作者: 余霜 (1982一), 女, 四川泸州人, 博士, 教授。主要从事农业资源与环境经济管理研 究。E-mail: ysling77@sina.com。

\section{参考文献:}

[1] 邵秀英，王红，王向东，等．高等师范地理教育实习现状与规范性研究 [J]．教育理论与实践，2005，（14）： 59-61.

［2］肖灵．高师院校中文专业教育实习改革的思考 $[J]$ ．教育与职业，2009，（12）：149-151． 
[3] 钱国旗. 综合性大学教师教育改革与发展的策略思考 $[J]$ 。青岛大学师范学院学报，2005，（01）：92-97.

\section{References}

[1] X.Y.Shao, H.Wang, X.D.Wang, etc: Research on Present Condition and Standadization of Geography-Education Practice in Normal College[J], Theory and Practice of Education, 2005,(14):59-61.(In Chinese)

[2] L.Xiao: Reflections on the Reform of Chinese Major Education Practice in Higher Normal Colleges and Universities[J], Education and Vocation, 2009,(12):149-151.(In Chinese)

[3] G.Q.Qian: Reflection on the Tactics of the Reform and Development in Education forUniverstity Teachers[J]. Journal of Teachers College Qingdao University, 2005,(01):92-97.(In Chinese) 